\title{
From the History of Religions to the Study of Religion in Denmark: An Essay on the Subject, Organizational History and Research Themes
}

\author{
TIM JENSEN \& ARMIN W. GEERTZ \\ University of Southern Denmark \& Aarhus University
}

\begin{abstract}
The history of the academic study of religion in Denmark resembles developments in other Nordic and European countries as it has moved from a primarily historical-philological and comparative 'history of religions' towards a broader 'study of religion(s)' that includes history of religions together with theories and methods from a wide variety of the human, social and today also natural sciences. Uppsala University was one of the three main centers of positivism at the end of the 19th century, and its influence was evident and long-lasting also in Denmark. By the end of the 1970s, debates and reflections on methods and theories slowly began to have a greater impact, and from the mid-80s and especially mid-90s, also due to conscious efforts not least in Aarhus, methodological issues gained in importance. A turn towards contemporary religion also became evident. Today it may be claimed that a kind of balance has been achieved whereby historical and empirical studies of religions go hand in hand with theoretical and methodological reflections, and where a balance between, on the one hand, more classical comparative history of religions materials and approaches, and, on the other hand, new and different areas of research, and new and different approaches and theories are of equal importance. With regard to individual research, research programs, and study programs, the history of the history of religions in Denmark cannot be described in detail here. This article presents the broad picture of important developments within and across the three Danish universities that have study of religion departments. Although the early histories are briefly touched upon, the focus will be on the past 50 years, from about 1960 until 2014, thus roughly the same period that Temenos has been in existence.
\end{abstract}

Keywords: Study of Religion, Denmark

Drawing a detailed picture of the development from a more classical 'history of religions' into what today is called the broader 'study of religion(s)', even if the focus is only on the past 50 years, is a vast and difficult task. The same goes for the more modest task of outlining the characteristics of 
the study of religion in Denmark during that period. ${ }^{1}$ In this article, we introduce the three universities that offer the study of religion in Denmark: Copenhagen, Aarhus and Odense. We have been highly selective, and the omission of many names of individual scholars and of most of their many publications is solely due to the limits of space here. Most publication references nowadays can be found at the relevant websites of the universities where the scholars are employed, and we therefore refer the reader to those websites. Institutional matters and changes are closely linked to changes within the study of religion, and thus will also be touched upon together with developments in study programs, individual and collective research initiatives, publications including journals, (more or less) learned societies as well as the characteristics and strong links between the study of religion and the teaching of Religion in the Danish upper-secondary schools (called Gymnasium in Danish). The story of the study of religion in Denmark does not begin with the establishment of a chair or a department at the University of Copenhagen. Many prominent scholars with importance for the academic study of religion did not and still do not have positions at a department for the study of religion but at other faculties, departments, or institutes. Our story, however, will begin with the chair in Copenhagen, and by and large we will limit ourselves to developments within the institutionalized study of religions departments.

\section{University of Copenhagen}

At the University of Copenhagen, ${ }^{2}$ the history of religions first became a university subject with the establishment of a Readership in the Faculty of Philosophy in 1900. Inspired by the establishment of similar chairs at the

\footnotetext{
1 The following draws heavily on Johansen 1979, Institut for Religionshistorie 1985, Nørr \& Jensen 1981, Nørr 1981, Stenbæk 1980 \& 1981, Bilde 1981, Smidt Hansen 1985, Geertz 1985, 1995 \& 1996, Tybjerg 1996 \& 2010, Jensen 2002, Geertz \& Jensen 2003. The name religionsvidenskab, used in Aarhus and Copenhagen, literally means 'science of religion', but is meant by its practitioners to mean 'study of religion', while religionsstudier, the name used in Odense, literally means 'religious studies', but is understood by its practitioners as 'study of religions', in the plural. In general, it can be argued that omission of the ' $s$ ' indicates that the main aim is the study of a theoretical object called 'religion', while the inclusion of the plural ' $s$ ' indicates a more historical study of various religions. However, in reality this is not always so. The same can be said about the EASR (European Association for the Study of Religions), the Danish Association for the Study of Religions, and the IAHR (International Association for the History of Religions), where the 's' does not indicate a lack of interest in the theoretical object 'religion' and thus religion in general.
}

2 The University was founded in 1479. 
major universities in Europe, the Faculty thought it a good idea to host the scientific investigation of what was at the time called 'the spiritual life of mankind' ('det menneskelige Åndsliv' - Tybjerg 1996, 23; 2010, 241ff.).

The position was awarded to Edvard Lehmann (1862-1930), whose major work was a two-volume book on Zarathustra. ${ }^{3}$ Lehmann left Copenhagen for a chair in Berlin in 1910. The Readership in Copenhagen was taken the next year by Vilhelm Grønbech (1873-1948) who already in 1912 published his three-volume book on the Old Norse religion. On the basis of that opus, Grønbech was called to the chair in Leipzig, but the University of Copenhagen then established a full Professorship for him, which he accepted in 1915.

Grønbech has had a considerable impact on the study of religion in Denmark (see Tybjerg 2010, 267 ff.). His approach was a blend of historical and philological textual studies and a (claimed) intuitive empathy (via the reading of the texts). His publications were numerous and voluminous and covered a large number of topics. ${ }^{4} \mathrm{His}$ impact also extended to broader cultural issues in which he engaged in writings aimed at a wider public.

The same year Lehmann left for Berlin, a number of church communities in Copenhagen worked towards the establishment of a university education in Christian Studies (Kristendomskundskab) for teachers of Religion in the gymnasium (upper-secondary school). Their goal was to improve the pedagogical and scholastic quality of teaching in Christianity, which was the subject being taught in the schools at the time. Many of the young theologians and priests teaching at the time had great pedagogic and disciplinary problems - and not all of them were as devout as the church communities

3 Lehmann 1899-1902. His international breakthrough, however, came with the German, Dutch, English and Swedish translations (during the period 1908-1915) of a book on mysticism in heathen and Christian contexts. See also Sand \& Sørensen 2001.

4 Topics ranged from mysticism to Hellenism and Christianity as well as literary figures in England and Germany. See Grønbech 1909-1912, 1913, 1915, 1922, 1932-1934, 1935, 1940a, 1940b, 1941, 1942 \& 1944-1945. There are a growing number of studies on his influence and thought, and in 1994 a Grønbech Society was established to encourage studies of his influence on Danish science and culture. See Tybjerg 1996 and 2010 for references to publications on the work of Grønbech.

5 While the subject in the upper-secondary schools was named Religion, the names given to the university subject and study program as well to the department or institute housing or administering the subject have been many - and the name of the subject has not always remained the same as that of the department or institute. In the following, we make mention of some of the changes in name(s), concentrating, however, on the development of the subject and study program away from being a kind of 'mini-theology' towards a 'mini-study-of-religions' subject. 
wanted them to be. ${ }^{6}$ But the Ministry of Culture (Kultusministeriet) was not interested in promoting the Christian goals of the movement, and wanted the history of religions to be integrated into the educational program, and the Ministry also asked the Faculty of Theology to reorganize its educational program so that theological students could receive a more humanist education. These initiatives rankled a large number of religious interest groups, and it took several years before the new educational program was established. The Ministry did not succeed in their two-fold goal, but they did succeed, if not entirely and immediately, in severing Christian Studies from Church influence.

The educational program established in 1912 was based on an uneasy cooperation between the Faculty of Theology and the Faculty of Philosophy. The program was under the auspices of the Faculty of Philosophy, but the four theological disciplines (Old Testament, New Testament, Systematic Theology and Church History) were taught by professors from the Faculty of Theology, whereas the courses in the history of religions were taught by the chair at the Faculty of Philosophy. Unfortunately, the students had no real place of their own in this uneasy alliance, and, more importantly, only they (as opposed to their teachers) were in the position to attempt a synthesis of these diverse disciplines. Christian Studies became an arena of strife between theology and the history of religions, and it was hampered for decades by an identity crisis. On the other hand, Christian Studies educational programs, slowly but surely developing from 'mini-theology' to 'mini-study-of-religions', fully integrated in the general study programs of the three universities, ${ }^{7}$ have also been one of the most significant factors in the economic and institutional success of the study of religion in Denmark. In what follows, we shall pay special attention to it wherever relevant.

Grønbech's successor in 1943 was Svend Pallis (1894-1972). Like his teacher, Pallis placed strong emphasis on the study of texts. Hypotheses and theories were clearly of subordinate value to texts in the original language. His dissertation on Mandaism of 1918 met a great amount of resistance from the founders of Mandean studies, but his main work on The Babylonian Akitu

\footnotetext{
6 See Nørr 1981, 28. See the same also for the state of affairs prior to 1912, both as regarding the school subject and the education and educational background of the Religion teachers (who were mostly graduates in theology, some of them also ministers).

7 Portions of the history of this development are analyzed and described in chapters in Nørr and Jensen 1981, and in Institut for Religionshistorie, Aarhus 1985. For other aspects of the close relationship between religion in the secondary schools and the academic study of religions, see Jensen 2007, and Jensen \& Kjeldsen 2013.
} 
Festival (1926) is still worth reading. ${ }^{8}$ Though Pallis, as noted by Tybjerg (2010, 279), did not share Grønbech's interest in religious mentality or psychology (and did not think it possible to access it), he shared and contributed to the continuing interest in the dynamic relations between myth and ritual that has characterized much of Danish studies of religion. Another of Pallis' concerns was to explain the supposed differences between 'primitive religions' and urban religions, a concern which came to influence one of the main figures in the sociology of religion in Copenhagen, Arild Hvidtfeldt.

Arild Hvidtfeldt (1915-1999), who began his studies in religion in the 1940s after studies in economics and a career in journalism, published his dissertation in 1955 on Teotl and *Ixiptlatli: Some Central Conceptions in Ancient Mexican Religion. Apart from elaborating on the relationship between primitive religions and urban religion, Hvidtfeldt also tried to develop and refine basic typologies and terminological issues, and his work on Aztec religion furthermore opened the door to that of the Near East, Greece and Rome (Tybjerg 2010, 282). Hvidtfeldt's publications were numerous and covered a large number of topics. In a manner characteristic of most sociology of religion in Copenhagen, Hvidtfeldt combined historical and textual analyses (like historians of religions) with more sociological and anthropological approaches. Worth noting is the fact that already in 1961 Hvidtfeldt wrote a textbook for the upper-secondary school, which influenced the teaching of Religion at that level for decades. ${ }^{9}$ Hvidtfeldt also edited and contributed to several series of handbooks and introductions to religion in general, for instance, in the series Verdens Religioner (Politikens Forlag, 1982ff.).

When Pallis retired in 1964, it was not Hvidtfeldt but Jørgen Prytz Johansen who succeeded him. Hvidtfeldt, however, was called in 1970 to a new chair linked to the establishment of the Institute of Sociology of

8 His critical edition of Greek religious texts (1948) was for decades on the curriculum of students in the history of religions and in Christian Studies.

9 Several of Hvidtfeldt's students and later sociologists of religion (e.g. Peter B. Andersen, Annika Hvithamar, Tove Tybjerg, Aase Koefoed, Morten Warmind) followed in his footsteps by publishing textbooks for the upper-secondary school. For a review of some of these and textbooks written by other religion scholars (e.g. Jørn Borup, Dorthe Refslund Christensen, Marianne Qvortrup Fibiger, Armin W. Geertz, Tim Jensen, Jeppe Sinding Jensen, and Mikael Rothstein), see Jensen 2007, 342. Mention should also be made of the 1978 University of Copenhagen Gold Medal thesis by Margit Warburg (Warburg 1978) which perhaps can be seen as the first study-of-religion work on the didactics of religion education. Besides the work later done on this topic by Tim Jensen in Odense, it has, inter alia, also been pursued by Niels Reeh, a doctoral student of Warburg (Reeh 2006). Another of Hvidfeldt's students to be mentioned is Jens Henrik Vanggaard whose 1988 doctoral dissertation The Flamen with its subtitle A Study in the History and Sociology of Roman Religion is also indicative of the close relationship between sociology and history of religion in Copenhagen. 
Religion (with American Indian Languages and Cultures) at the Faculty of the Humanities.

Prior to his career as a scholar of religion, Jørgen Prytz Johansen (19111989) was educated in physics and worked as a librarian at the University Library in Copenhagen. He followed more directly in the footsteps of Grønbech than did Pallis or Hvidtfeldt. His dissertation The Maori and His Religion in Its Non-Ritualistic Aspects (1954) was an exemplary historicalphilological analysis of the texts relevant to a study of Maori culture and religion, and both in this work, and in his analysis of the key Maori rituals and myths (Studies in Maori Rites and Myths, 1958) and his writings about the Zuni, Prytz Johansen tried to frame and center his analysis within a Grønbech-like concept of the respective cultures as integrated units. ${ }^{10}$ His Maori dissertation was recently rediscovered by leading anthropologists and republished as volume 1 in the HAU: Classics of Ethnography Theory Series, with an introduction by Marshall Sahlins, and a biographic note by one of Prytz Johansen's students, Bo Alkjær. In his introduction, Sahlins characterizes the work of Prytz Johansen as a 'brilliant work of comparative ontology - the highest form of anthropology'.11

As mentioned below in the section on developments in Aarhus, Prytz Johansen and Halfdan Siiger worked closely together in developing the study programs in Aarhus and Copenhagen, and to a large degree, they shared the same vision of what ought to constitute the discipline of the history of religions. The study program they agreed on in 1967, which was decisive for the departments and disciplines throughout the 1970s and later, may be seen as exemplary for what was at the time the commonly agreed core 'knowledge areas' and 'competencies', namely the religions of indigenous peoples (called at the time 'primitive cultures' or 'nature people religions'), the religions of what was considered to be the most important 'high cultures' of the Near East (Mesopotamia, Israel, Egypt, Greece), Greco-Roman and Hellenistic religions, and the most important foreign 'higher' religions (Buddhism, Hinduism, Taoism, Confucianism, Shinto, and Islam). The study program also included the phenomenology of religion and the history of the study of religion, and, worth noticing, a required more in-depth examination in one of the religions of indigenous peoples. It was furthermore required that the primary texts of one of the areas or religions studied should be studied in the original language. The study program thus reflects Prytz Johansen's and

10 On Prytz Johansen, see Tybjerg 2010, 283-85 with references, and Alkjær 1989.

$11<$ http://www.haujournal.org/index.php/classics/issue/view/Classics\%20Series\%201/showToc $>$, accessed April 11, 2014. 
Siiger's understanding of an historian of religions as a scholar of religions who masters the language and history of one religion while at the same time maintaining an extensive comparative perspective based on a knowledge of a wide variety of religions and religious phenomena, past and present. It also reflects the importance that both Siiger and Prytz Johansen paid to ethnographic studies of religion, even though Prytz Johansen, as mentioned by Bo Alkjær in his 'Biographic note' to the above-mentioned reprint by $H A U(\mathrm{xi}-\mathrm{xv})$, never carried out fieldwork, nor even visited New Zealand. ${ }^{12}$

With special regard to the aforementioned education of teachers of Religion in the upper-secondary schools, mention should be made of an organizational change which had more than an administrative impact on later developments. In 1973, the subject Christian Studies, which for a long time was administered by the Faculty of Theology with teachers from that faculty (except of course in the discipline of the history of religions), became a section within the Institute of History of Religions.

When Prytz Johansen retired in 1981, his chair remained vacant. A historian of religions, Associate Professor Vagn Duekilde, served for many years as head of the Institute. Duekilde was a specialist in Greek Religion, ${ }^{13}$ a field of study also dear to Prytz Johansen. Duekilde also lectured on Old Norse religion, with the use of the source material in the original language, thus contributing to and prolonging the historical-philological-cum-comparative tradition in Copenhagen. Duekilde, furthermore, was responsible for several translations into Danish of key works of two important scholars of religion, namely Georges Dumezil and Mircea Eliade. ${ }^{14}$

In Copenhagen (as well as in Aarhus and Odense), the 1980s brought a series of changes and transformations of great importance. Following the 1972 establishment of an Institute of Sociology of Religion and the 1973 inclusion of Christian Studies into the Institute of History of Religions, the Institute of History of Religions (with the sections History of Religions and Christian Studies) and the Institute of Sociology of Religion (with American

12 This in contrast to one of Prytz Johansen's students, Torben Monberg (1929-2007) who carried out extensive fieldwork on Renell and Bellona Islands in the Solomon Islands. See Monberg 1991. It is worth mentioning that Monberg, who did not hold a position at the Institute of History of Religions, joined the large number of Danish scholars of religion who published textbooks for the upper-secondary schools (Monberg 1978).

13 Duekilde edited the 1997 volume on Hellas i Klassisk Tid. Græsk Religion in Spektrum's series Verdensreligionernes Hovedværker, a series intended to succeed (or revive) the 'classical' 1920s series of the same name edited by Poul Tuxen and Aage Marcus.

14 Eliade 1949 (1966 translation) and Dumezil 1959 (1969 translation). Duekilde also translated Eliade's three-volume history of religious ideas 1978 (translations 1983 and 1995). 
Indian Languages and Cultures) were merged in 1982 into the Institute of History of Religions with the named sections that to a large extent continued following each their own independent paths. Sociology of Religion, furthermore, was housed elsewhere. The lecture society Religionshistorisk Forening ('History of Religions Society') as of 1980 and the journal CHAOS as of 1982 (see below) helped, however, to provide a meeting place for all lecturers ${ }^{15}$ and students. The institute, furthermore, in 1984 hosted an international symposium on 'Religions of Late Antiquity' (cf. Sørensen 1989).

In 1985, an undergraduate study program common to the three sections was introduced, forcing them, as it is phrased in Årbog for Københavns Universitet ('Yearbook of the University of Copenhagen', 1985, 516) to discuss 'the contents of the subjects, what they have in common as well as their fundamental different characteristics.' Also in 1985, Christian Studies changed its name to the History of Christianity (Kristendomshistorie). ${ }^{16}$ The basic educational program initiated in 1985 has been revised and changed time and again (it is now a Bachelor program with an added Master's degree). In Copenhagen, the three 1985 sections for years have offered each their own candidate/MA study program and degree. Some years ago, however, the History of Christianity was merged at the MA level into History of Religions.

In 1985, several of the scholars who since then have constituted the backbone of the staff were, in one way or another, students of Prytz Johansen and Hvidtfeldt. Associate Professor Tove Tybjerg, then as now, specialized in American Northwest Coast Indians, the history of the study of religion,

15 In 1982 the staff counted one professor, Hvidtfeldt, six associate professors: Duekilde (History of Religions); Carsten Breengaard, Jørgen Skafte Jensen and Paul Müller (Christian Studies); Una Canger (American Indian Languages and Cultures); one assistant professor Tove Tybjerg (Sociology of Religion); and three research scholarships (Inge Schellerup, Merethe Sundby-Sørensen, and Margit Warburg), plus six external lecturers and teaching assistants. 16 The information we have on the changes in names of the subject and education for Religion teachers in the 1980s and early 1990s is incomplete. At some point it was called, if not formally named, 'religion/kristendomskundskab' and (perhaps in 1990) just 'religion'. In Copenhagen as well as in Aarhus the most important thing is that, despite the name(s), the future teachers in Religion gradually began to be educated in a more study-of-religions manner, even though their curricula included more Christianity, especially New Testament original-language-based exegesis and religion-related philosophy and contemporary theological positions (Breengaard 1993). Due to this emphasis on Christianity, it was not until 1996 that someone holding a degree in sociology or history of religions was recognized as qualified as a teacher in Religion for upper-secondary schools. It is a curiosity worth mentioning that Tim Jensen with his Mag. Art. degree in history of religions already became qualified in 1981 as a teacher of Religion. His doctoral-level Magister degree seemed for some reason to have over-ridden the requirements for upper-secondary school teachers, even though the degree at that time implied no exams in Christianity at all. 
and theory and method in the study of religion. Associate Professor, and currently Professor, Margit Warburg (see below) specialized in the sociology of religion, Baha'i religion, globalization and method and theory in the study of religion. Assistant Professor, currently Associate Professor, Erik Reenberg Sand specialized in classical Hinduism. And though not mentioned under 'staff' in the Yearbook, Jørgen Podemann Sørensen was also at the institute with a project on religious knowledge in Pharaonic and Hellenistic Egypt. But it was not until 1987 that Podemann Sørensen, who has published widely on themes within theory and methodology in comparative religion (or phenomenology of religion), especially ritual (see e.g. Sørensen 2012), was hired as Assistant Professor and currently is Associate Professor. History of Christianity scholars Carsten Breengaard, Jørgen Skafte Jensen, Lars Kruse Blinkenberg, and Paul Müller were also active, lecturing and doing research, and apart from Paul Müller who at some point moved (back) to the Faculty of Theology, these scholars had great impact on the Institute of History of Religions well into the 2000s. Other students of Prytz Johansen (Bo Alkjær on Greek religion and Tim Jensen on Greek religion) were hired as teaching assistants during the 1980s and they both, not least through Religionshistorisk Forening and CHAOS, were also active in the milieu at the institute.

In 1991, the Faculty of Humanities decided that the Institute of History of Religions was to move from the old university area in central Copenhagen to Amager, a location described by the then head, Carsten Breengaard, as a move to a 'second class seminary building in a garden plot quarter' (Årbog 1994, 348). ${ }^{17}$ Sociology of Religion moved in 1993, History of Religions in 1994. The increase in the number of students joining the common undergraduate study program during the early 1990s was noteworthy.

In 1993, Mikael Rothstein received his PhD degree with a dissertation on The Relation Between Science and Religion in Transcendental Meditation (TM) and the International Society for Krishna Consciousness (ISKCON), thus paving the way for other scholars of religion to focus not only on religions of the past but also on contemporary religion, including new religious movements, New Age and the like. This also made the lines of demarcation between the historians and sociologists of religion more blurred than they already were thanks to the Copenhagen kind of sociology of religion

17 Danish: Andenklasses seminariebyggeri iet kolonihavekvarter. Breengaard graduated in Christian Studies and History and earned a doctoral degree in Theology (Breengaard 1982). His academic work may be mentioned for its contribution to adding a stronger humanistic emphasis to Christian Studies/History of Christianity. 
mentioned above. Rothstein, soon to become a prominent scholar of religion, due to his many publications on new religious movements (see also below on RENNER) as well as to his skills in sharing his study-of-religions based knowledge about religions with a wider public, became Associate Professor in 2001.

Another change of address, this time though within the Amager areas, was followed in 2004 by an important change in organization, most likely of some importance to what has now become the 'sections' of History of Religions and of Sociology of Religion within the Department of Cross-Cultural and Regional Studies (Institut for Tværkulturelle og Regionale Studier-TORS). ${ }^{18}$ Both in terms of the 'cross-cultural' and the 'regional', this merger made new kinds of collaborative research possible which could, perhaps, lead to new ways of conceiving the study of religions. Today there are no longer any sections but only various subjects or study programs.

Currently there are two full professors, ${ }^{19}$ respectively linked to history of religions and sociology of religion (still two separate MA study programs), namely Catharina Raudvere and Margit Warburg. ${ }^{20}$ The two of them and other staff have been engaged in several collaborative research projects over the last decade. Some of them, as it is noted in the 2003 Yearbook (479) have been in close cooperation with the Faculty of Theology, some with other scholars from University of Copenhagen, and some also including international scholars. ${ }^{21}$

18 See $<$ http://tors.ku.dk/>

19 As for changes in staff and research over the last 15 years or so, readers are referred to the relevant sections in the yearbooks (up to 2006) of the University of Copenhagen, available online <http://publikationer.ku.dk/aarlige_udgivelser/aarbog/>.

20 In 2005, Raudvere became professor in History of Religions, the chair having been vacant since Prytz Johansen's retirement in 1981. See Raudvere 1993. Raudvere is a member of the Danish Royal Academy of Sciences and Letters. Margit Warburg held a Research Council of the Humanities professorial chair from 2004-2009, and Professor in Sociology of Religion in 2010. See Warburg 2006.

21 Of the many projects, mention should be made of the following: Religion in the 21st Century, a large cross-faculty research focus area running from 2003-2008. Warburg was a member of the steering group. Warburg was active in Alternative Spaces. Cultural Awareness and Cross-Cultural Dialogues (2008-2012), and she is currently director of the research network Den danske religionsmodel under forandring ('The Changing Danish Religion Model'). Warburg herself is currently doing research on religion among Danes abroad, theories of religion and migration, religion and demography, religious minorities and civil religion. Warburg has also published widely on religion and globalization and has been active in earlier research projects such as RENNER (see below). Raudvere has been engaged in Exile and Tradition. Transnational Contemporary Sufism (2009), Between Conservative Reaction and Religious Innovation. Religious Intellectuals in Central and South-Eastern Europe on Community (2010), Authenticity and Origin, Muslim Devotion (2011), and The Many Roads in Modernity. The Transformation of South East Europe and Its Ottoman Legacy from the 1870s to the 21st Century (2012-2016). Raudvere has published widely on subjects related to the mentioned research projects, on Sufism, identity, globalization and migration, while at the same time publishing on pre-Christian Scandinavian religion. 
Both professors have supervised a good number of PhD students, some of whom later became employed at the same institute or section playing their roles in Danish study-of-religions scholarship. Mention may be made here of a few of them: Annika Hvithamar (Russian Orthodox Christianity and the Russian State and Iconography, Civil Religion), Niels Reeh (see above), and Brian Arly Jacobsen (Representations of Muslims and Jews in parliament politics; religion and demography in Denmark).

Currently, the staff in Copenhagen consists of two professors, seven associate professors (sociology of religion: Peter B. Andersen, Tove Tybjerg, and Morten L. Warmind; history of religions: Erik Reenberg Sand, Jørgen Podemann Sørensen, and, with special emphasis on Christianity, Annika Hvithamar and Peter Westergaard), and one assistant professor (sociology of religion: Brian A. Jacobsen) and a post-doc researcher (sociology of religion: Niels Reeh). Two positions as associate professors in history of religions and sociology of religion respectively (or: religions in Antiquity and contemporary religion) are in the process of being filled. There are some 9 external lecturers and several $\mathrm{PhD}$ students. The number of students as of the end of 2012 was approximately $296 .^{22}$

\section{Aarhus University}

Grønbech also had an impact on the history of religions in Aarhus, because it was one of his students who filled the chair that was established there in 1960. In the 1950s Aarhus University offered a MA degree in Christian Studies, located within the Faculty of Humanities. As in Copenhagen, students were taught the theological disciplines by teachers from the Faculty of Theology, whereas courses in the History of Religions were offered by Professor Svend Aage Pallis from the University of Copenhagen a few times a year when he was in Aarhus. This situation was not optimal, and after several years of negotiations, beginning in 1953, between the Faculty of Theology and the Faculty of Humanities, Museum Inspector Halfdan Siiger was hired in 1960 as Professor in the History of Religions. Siiger was a member of Henning Haslund-Christensen's Third Danish Central Asian Expedition to Afghanistan, Pakistan and India. Siiger participated in the expedition from 1947-1950. He pursued ethnographic fieldwork among the Kalashas in Chitral in 1948, the Lepchas in Sikkim in 1949 and the Boros in

22 Thanks are extended to Morten Warmind for the latter piece of information as well as to Catharina Raudvere, Tove Tybjerg, Margit Warburg, Bo Alkjær and Jørgen Podemann Sørensen for providing important information regarding the past and present situation. 
Assam in 1950, whereupon he returned with valuable objects, photographs, manuscripts and notes. Even though he did not succeed in publishing all of his findings, his manuscripts and photos are still of importance today. ${ }^{23}$

Although Halfdan Siiger was hired by the University of Aarhus primarily to establish an Institute of the History of Religions, Siiger was involved in much more than establishing the institutional framework for the Institute, its study programs and research environment. He was also involved in developing the study programs and courses for Christian Studies that allowed students to become teachers in the non-confessional subject of Religion in the upper-secondary schools. In 1967, Siiger also became a member of an important national committee, established by the Ministry of Education, charged with the task of analyzing the teaching of religion on the various levels in the school system as well as in teacher training. The work of the committee included recommendations for improvements, and it exercised an important influence on the relevant school subjects. Siiger as well as Erik Haahr (see below) also were actively engaged in other projects linking the academic study of religions to the teaching of Religion in the schools. ${ }^{24}$ Siiger was also involved in establishing the discipline of Ethnography at the University of Aarhus.

As mentioned above, Siiger's vision of the history of religions as the study of religions in the ancient worlds of the Near East and Asia, modern world religions and the religions of indigenous peoples and tribes was shared by Prytz Johansen in Copenhagen, and the two in close collaboration established a new curriculum in 1967, to be shared by both Aarhus and Copenhagen, based on this vision. The basics of that curriculum later served as the basis for a full educational program comprising the 2-year Cand. Art., the Cand. Phil. [approximately a Master's], and the Mag. Art. higher degree (1970 and 1972), and remained the backbone of later study-of-religions programs.

Although Siiger was interested in the empirical and particular rather than in the theoretical and reflective dimensions, he knew that both dimensions were important. Thus, because of his style of scholarship and teaching, the many exciting philosophical, linguistic, anthropological and literary theories on religion and other subjects that swept through most disciplines during the 1960s and 1970s, were considered to be secondary to the study of reli-

23 See his preliminary report of 1956. Siiger did manage, however, to publish some of his Lepcha material before he died in 1999 (Siiger 1967). The rest of his material is being edited with commentary and contributions by representatives of the Central Asian peoples that he visited. One example of such publications is Mytte Fentz 2010.

24 Cf. Smidt Hansen 1985, 14. 
gious texts and ethnographic and historical descriptive accounts. Siiger's academic stance thus led to many discussions and debates with colleagues and students in other humanist disciplines, also at the Faculty of Theology, but Siiger firmly and politely maintained his stance.

As the Institute as well as the number of students grew, the university hired two Associate Professors, Erik Haarh (Tibetan and other Asian religions) and Bent Smidt Hansen (Christianity in India and the Phenomenology of Religion). Smidt Hansen was specifically hired to improve cooperation with Christian Studies. Haarh and Smidt Hansen were furthermore assisted by scholars of Greek Jep Scavenius and, after his retirement, Gert E. Skov.

The group of scholars and students in Christian Studies gradually developed during the period of 1965-1970, and in 1971, it became an independent research and education Institute of Christian Studies. During the period of 1970s, the staff and students spent considerable critical, theoretical and methodological efforts in extracting the Institute from its reputation as 'mini-theology' in order for it to become a full-fledged institute of religious studies (Religionsstudier). This was of course difficult since several of the Associate Professors were theologians by education. This was true of Per Bilde (New Testament, early Christianity and Hellenistic studies), Jørgen Stenbæk (church history; followed by Christian Studies candidate Per Ingesman after his retirement), Svend Bjerg (philosophy of religion and history of ideas; followed by Vagn Andersen after Bjerg left for a position in Copenhagen), and Niels Peter Lemche (Old Testament). When Lemche left for a position in Copenhagen, one of the first graduates from Christian Studies, Kirsten Nielsen, took over Old Testament research and education. Ole Riis, who was a sociologist, was hired to run the sociology of religion discipline at the Institute. ${ }^{25}$ During the 1980s, a young generation of Christian Studies scholars became attached in assistant positions (Ole Davidsen with semiotics, Hans Jørgen Lundager Jensen with Near Eastern studies and structuralism, and Jytte Gudiksen with New Testament, to name a few). It was not until 2001 that the Institute was given a professorial chair. The chair was taken up by Per Bilde (see Bilde 1983). This group of dedicated staff, together with the staff at the Institute of the History of Religions, further developed non-confessional Christian Studies into a true study of religions, and in 1980, the study program at the Institute (still) called Christian Studies was named 'Religion', and the cooperation between this institute and the

25 The fact that Ole Riis was a sociologist by education and was hired by the Institute of Christian Studies, in contrast to the sociology of religion in Copenhagen, which grew out of the history of religions, gave the discipline two different profiles. 
Institute for History of Religions became even stronger. Through the efforts of Bent Smidt Hansen, the study of Christianity was extended to include Christianity outside of Europe and North America, and consequently the 'phenomenology of Christianity' was offered. ${ }^{26}$

In 1982, the Institute of the History of Religions was transferred from the Faculty of Humanities to the Faculty of Theology due to financial difficulties in the Faculty of Humanities. Siiger's professorial chair, which had been vacant since his retirement, was filled by Dr. Phil. Erik Haarh (see Haarh 1969), who was called to the Chair in 1983. There were three Associate Professors: Armin W. Geertz, who specialized in indigenous peoples' religions, Jens Peter Schjødt, who specialized in the Old Norse religion, and Jeppe Sinding Jensen, who specialized in Islam and in method and theory in the study of religion. Erik Haarh retired in 1987, and, in 1995, Armin W. Geertz took over the Professorial chair (see Geertz 1992). ${ }^{27}$

In 1985, the Institute of the History of Religions and the Institute of Christian Studies established a partially merged study program. In 1990, the two Institutes were completely merged into the Institute for the Study of Religion (Religionsvidenskab) with completely merged study programs. This merger proved to be a dynamo that led to very strong research and teaching profiles as well as fruitful cooperation with colleagues at various departments in the Faculty of Theology, especially the departments of biblical studies and church history. The Institute hosted regular seminars and conferences as well as two monograph series, published during the late 1990s and early 2000s by Aarhus University Press, one in Danish and the other in English: Religionsvidenskabelige Skrifter ('Study of Religion Monographs') and Studies in Religion. ${ }^{28}$

Three important developments should be mentioned in this connection. The first occurred in 1995, when Armin W. Geertz in his inaugural lecture (Geertz 1995) launched a call for the development of the study of religions in Aarhus, which was explicitly in line with the declaration issued at an IAHR expert conference on 'Studies on Religion in the context of the Social Sciences: Methodological and Theoretical Relations' in Warsaw in 1989. A central aim of the delegates to Warsaw as well as of Geertz, was to make

\footnotetext{
26 Smidt Hansen 1985, 20.

27 Because of the economic situation in Denmark, the three permanent chairs in the study of religion remained vacant until 1995. For the next 10 years, Geertz was the sole permanent Professor in the study of religion in Denmark.

28 Three books were published in the English series and six in the Danish series. The editorial boards consisted of colleagues from Aarhus, Odense and Copenhagen. Per Bilde was the Editor-in-Chief for several years, followed by Armin W. Geertz.
} 
possible 'a shift in attention to the meaning of religion in social interaction', and an 'evaluation and use of innovative social theories and models as well as those from cognate disciplines." ${ }^{29}$ Inspired by the theoretical challenges brought to Aarhus by Jeppe Sinding Jensen, who had been employed in Odense at the Institute of Philosophy (see below), and critical debates with colleagues in Christian Studies, Geertz and colleagues worked towards a new era of post-empiricism or post-positivism, and urged historians of religions to rethink their enterprise. The traditional, historical-philological, comparative and textual competencies needed to be critically re-examined and supplemented by theories and methods from the social and cognitive sciences, from linguistics, from the philosophy of human and social sciences, from discourse analysis, narratology, semiotics and so on. It must, Geertz insisted, be able to cope with post-modern criticisms like the issues of orientalism, the construction of the exotic, the misrepresentation of other cultures, the politics of science and feminist criticism, etc. ${ }^{30}$ These theoretical interests led to an institutionalization in the form of the Theory of Religion Laboratory at the Institute of the Study of Religion, which was established by Anders Klostergaard Petersen and Hans Jørgen Lundager Jensen, but which quickly encompassed a large number of colleagues at the institute. ${ }^{31}$ It also led to the publication of a monumental study by Jeppe Sinding Jensen on these issues entitled The Study of Religion in a New Key (2003) in which he discusses most of the theoretical, methodological and epistemological aspects of comparative religion as practiced in Scandinavia.

The second development concerns the study of New Religious Movements, dominated until the middle of the 1990s by the mission and ecumenical theologian Johannes Aagaard, who during the 1970s had established a research and information center called Center of New Religious Studies. His mostly confessional activities were strongly criticized in the public media by the young historian of religions Mikael Rothstein at the University of Copenhagen, who specialized in new, contemporary religions. Both of them had applied for funding from the Danish Research Council of the Humanities. The Council, knowing full well about the conflict between the two, asked them to combine their resources and cooperate. Armin W. Geertz was appointed as the Chair of a new Research Network on New Religions (RENNER), which ran from 1994-2002, and successfully ensured cooperation between theologians, historians of religion and sociologists

29 Geertz 1989, 108. These concerns were formulated in Tyloch 1990 and Pye 1989.

30 See Geertz 2000a \& 2000b and Geertz \& McCutcheon 2000.

31 For an overview see Geertz \& Jensen 2003. 
of religion. Besides Geertz, Rothstein and Aagaard, the board consisted of Ole Riis, Margit Warburg, Helle Meldgaard and Steffen Johannesen. ${ }^{32}$ Their activities consisted of editing and publishing an English monograph series and a Danish monograph series as well as hosting a series of conferences, seminars and conducting field surveys. ${ }^{33}$ Out of this cooperation, Aagaard's information center was reorganized after his retirement in 2001 into a theology and study of religion venture called the Center for Multireligious Studies, under the leadership of the ecumenical theologian Viggo Mortensen. After his retirement, the center was renamed the Center for Contemporary Religions (Center for Samtidsreligion) in 2009 under the leadership of Jørn Borup (history of religions, Buddhism and East Asia), followed in 2013 by Marie Vejrup Nielsen (contemporary Christianity and theology). Besides Borup and Nielsen, the team now consists of Lars Ahlin (sociology of religion, New Age and contemporary spirituality), Marianne Qvortrup Fibiger (history of religions, Hinduism and diaspora), Lene Kühle (sociology of religion, Islam and contemporary studies) and Henrik Reintoft Christensen (sociology of religion, methodology, religions in the media) as well as post docs and PhD students. The center has been very productive in publishing books and reports on the contemporary scene in Denmark and elsewhere. ${ }^{34}$

The third development concerns the new field of the cognitive science of religion. A group of scholars associated with the Theory of Religion Laboratory was successful in obtaining a small, initiatory grant from the University of Aarhus Research Foundation and the Faculty of Theology for a program designed to investigate the relations between religious narrative, cognition and culture. This research project, under the leadership of Armin W. Geertz and Jeppe Sinding Jensen, ran for 2003-2004 and was extended into the broader religion, cognition and culture project for 2004-2006. In 2006, the project was recognized as a permanent research unit called Religion, Cognition and Culture (RCC). The cognitive science of religion became integrated

32 During various periods other scholars were added and some retired. Mention can be made of Viggo Mortensen, Hans Raun Iversen, Dorthe Refslund Christensen, Annika Hvithamar and Finn Madsen.

33 These are RENNER Studies on New Religions, 7 volumes, Aarhus: Aarhus University Press, 1995-2003 and Gyldendal - Nye Religioner, 6 volumes, Copenhagen: Gyldendalske Boghandel, Nordisk Forlag A.S., 1995-2006. A number of independent publications were also released. 34 See their series of publications with the Danish publisher Univers (Højbjerg). So far, they have published eight volumes in connection with the 'Danish Pluralism Project'. See their website at http://samtidsreligion.au.dk/pluralismeprojektet/present/. They have also published a number of digital reports. 
into the Study of Religion curriculum and the RCC group attracted young scholars and PhD students from Denmark and abroad. A monograph series was established at Equinox, which later was transferred to Acumen, and is currently published by Routledge. ${ }^{35}$ Annual conferences were held and an extensive international research network was established. At a conference in Aarhus in 2006, the participants established the International Association for the Cognitive Science of Religion (IACSR) which after a few years also started a journal called Journal for the Cognitive Science of Religion. ${ }^{36}$

A significant turn of events in RCC history was the award in 2009 of funding from the Ministry of Research, Innovation and Technology to a coalition of scientists from all the faculties at Aarhus University. The funding was given by UNIK (UNiversitetsforskningens InvesteringsKapital / Investment Capital for University Research) and the coalition established MINDLab. The goals of this coalition were to address central scientific problems within culture, music, language and memory. These goals were to be achieved through the use of humanist, social, psychological, and psychiatric theories and methods together with novel technologies in examining the living brain, thus ensuring a combined top-down and a bottom-up approach. Through the use of new forms of teaching and sharing of knowledge, MINDLab explicitly exploited crucial synergies across traditional disciplines. What this meant for the RCC was a significant boost of capital which allowed the research unit to expand and thrive. Today the RCC is led by the troika of Armin W. Geertz, Jeppe Sinding Jensen and Jesper Sørensen (the latter a historian of religions specializing in ritual and magic) with a varying group of $\mathrm{PhD}$ students and post docs, several of whom have made international names for themselves, such as Dimitris Xygalatas (extreme rituals, firewalking and piercing in Greece, Spain and Mauritius), Uffe Schjødt (brain scan experiments of prayer and healing), and Kristoffer Laigaard Nielbo (studies of ritual, computer simulations and experimental theory and practice). The RCC is currently developing what they call the 'experimental study of religion'. RCC research was further strengthened by an award given by the university to a coalition to establish the Interacting Minds Centre. ${ }^{37}$

35 Religion, Cognition and Culture, edited by Jeppe Sinding Jensen and Armin W. Geertz, Routledge. There are currently six published volumes.

36 Armin W. Geertz is currently President and Jesper Sørensen is Secretary General of IACSR. See the website at $<$ http://www.iacsr.com/iacsr/Home.html $>$. The journal is published by Equinox Publishing Limited, and is edited by Pascal Boyer, Armin W. Geertz and Luther H. Martin together with managing editors Ryan McKay and Dimitris Xygalatas.

37 See the RCC website at $<$ http://rcc.au.dk/>, the MINDLab website at $<$ http://www.mindlab. au.dk/menu0-en $>$ and the Interacting Minds Centre website at $<\mathrm{http}: / /$ interactingminds.au.dk/>. 
In 2012, Aarhus University initiated a complete organizational restructuring. Since the Faculty of Theology was very small, it was disbanded, and its departments (Study of Religion, Theology, Arabic and Semitic Languages, and Sanskrit) were merged together with other departments (such as Anthropology, Prehistoric Archaeology, Classical Languages, History, Philosophy and several area studies) to form a Department of Culture and Society at the Faculty of Arts. The Study of Religion was organized as a section of Interdisciplinary Study of Religion, now simply the Study of Religion, covering four research units: History of Religions, the Center for Contemporary Religions, Religion, Cognition and Culture, and Arabic and Islamic Studies. The study program for the Study of Religion consists of a common Bachelor Degree and a Master's Degree consisting of three branches: History of Religions, Contemporary Religions, and Religion, Cognition and Culture. The Research Program that covers the four research units is currently exploring new evolutionary approaches to the history of religions, following Rappaport, Assmann, Jaspers, Eisenstadt and Bellah, but also incorporating evolutionary psychologists such as Merlin Donald, Terrence Deacon, Eva Jablonka and Jonathan Turner and Alexandra Maryanski. ${ }^{38}$

A final word should be said about the History of Religions research unit. It consists of many of the above-mentioned scholars who work either at the RCC or the Center for Contemporary Religions, as well as Anders Klostergaard Petersen (New Testament, early Christianity and Hellenism), Hans Jørgen Lundager Jensen (Old Testament and Near Eastern religions), Jens Peter Schjødt (Old Norse religions), ${ }^{39}$ Lars Albinus (Ancient Greek religions, history of ideas and philosophy of religion), and Marianne Schleicher (Old Testament and Judaistics). A new offshoot research unit on South Asian religion is being developed by Marianne Qvortrup Fibiger together with $\mathrm{PhD}$ student Bjarne Wernicke Olesen (Sanskrit) in cooperation with Oxford Centre for Hindu Studies in England.

Thus, the former Institutes of History of Religions and of Christian Studies in Aarhus have been merged several times and are now a section which has grown into a staff currently consisting of two permanent professors, two temporary professorships, nine Associate Professors, six post docs and

38 See the recent issue of Religionsvidenskabeligt Tidsskrift on Bellah (no. 60, 2013).

39 Anders Klostegaard Petersen and Jens Peter Schjødt became temporary professors, and Hans Jørgen Lundager Jensen became permanent professor. See Jensen 2004, Petersen 1994 and Schjødt 2003. 
research assistants and thirteen PhD students. ${ }^{40}$ The total number of students enrolled as of October 2013 is $324 .^{41}$

\section{University of Southern Denmark - Odense Od $^{42}$}

The University of Odense (OU; Odense Universitet) - since 1998 called the University of Southern Denmark (SDU; Syddansk Universitet) - was established in 1966 primarily to offload and supplement the universities in Copenhagen and Aarhus. Since the primary job of the Humanities was and still is to educate future teachers in the upper-secondary schools, the university established all of the scientific and scholarly disciplines whose subjects are taught there. And because all university students were required to take a philosophy course, the discipline of philosophy was also established. The University, however, did not have an Institute of the History of Religions or of Christian Studies that could provide education for Religion teachers, nor did it have a Faculty of Theology.

Towards the end of the 1970s, it was decided that all of the major subjects in the upper-secondary schools should be offered at the five universities in Denmark: Copenhagen, Aarhus, Odense, Roskilde and Aalborg, while the minor subjects could be offered as minors. In Odense, a committee was appointed in August 1978 to explore the possibility of establishing a minor in Christian Studies. As already mentioned, this was at the time the name of the subject at both Copenhagen and Aarhus. Because of the fairly significant differences in requirements for, on the one hand, the subject Religion in the upper-secondary school, and on the other, the Christian Studies programs in Copenhagen and Aarhus, the committee proposed a program which they thought provided future Religion teachers with a better education. Besides the traditional subjects of the History of Religions, Old Testament, New Testament and Church History, the committee proposed a hermeneutical discipline, Sociology of Religion and elements of the Psychology of Religion.

\footnotetext{
40 See the section website at $<\mathrm{http}$ //cas.au.dk/en/about-the-department/programme-profiles/ study-of-religion/>.

41 Information from the Head of Curriculum, Lene Kühle.

42 Our gratitude is extended to Niels Thomassen who kindly provided us with valuable information concerning the establishment and history up to 1999 of the University of Southern Denmark Odense. The quotes in this section are from Niels Thomassen's presentation of the program (Thomassen 1982). For the period from 1999 to 2014, we have made use of yearbooks from the University of Southern Denmark. As of 2002, the yearbooks (Årsberetninger) were made public only in digitalized form, and after 2008, the university no longer published these yearbooks. For the yearbooks of 1999-2008, see <http://www.sdu.dk/om_sdu/dokumentation_tal/aarsberetning>.
} 
The committee proposed that a Department of Religion should be established at the Institute of Philosophy, and the subject Christian Studies should be placed there with its own curriculum committee. They also proposed that the department should minimally consist of a professor, two associate professors and a number of part-time lecturers.

There was considerable resistance at the Institute of Philosophy to establishing Christian Studies. The end result, however, was a new Department (called Center) of Religion. Philosopher, Associate Professor Niels Thomassen volunteered for the new department, and he became the Chair of the committee that led to the full establishment of the subject. The final authorization was given in 1982 by the national Directorate of Advanced Education for the official establishment as a minor at Odense of the study program called Religion - a name thus identical to the name of the subject in the upper-secondary schools as well as to the name of the department (or Center) offering education in Religion.

The profile of the subject was to study 'all interpretations of existence that attempt to provide an understanding of humankind and its place in nature and the universe as a central perspective in those expressions that such interpretations take, whether religious, artistic or political'. The subject was thus concerned with 'religions, quasi-religious movements, and philosophical and ideological problems in their historical and actual manifestations'. The subject consisted of 'classical existential interpretations [...] and current philosophies of life and religious movements, also in terms of politico-religious societal changes and cultural clashes between differing interpretative regimes. ${ }^{43}$ In that connection, emphasis will especially be placed on those interpretive conceptions that are most important in understanding current events in the world.' Religions and other interpretive regimes were to be treated as regimes of knowledge and life-forms in their historical and cultural contexts. ${ }^{44}$

In order to improve employment possibilities for the candidates, each discipline consisted of a core study with flexible combinatory study elements. In that way, students were able to qualify themselves in what was

43 The text uses both helhedstolkninger - totalizing interpretations - and helhedskonceptioner - totalizing concepts, which we translate as 'regimes' in the sense of regimes of knowledge and beliefs.

44 Connecting religion and (non-religious) philosophies of life (livsanskuelser) in the manner done in Odense in 1982 and making it the profile of the study program resembles what is the case in the current Swedish subject of Religion in both elementary and upper-secondary schools. It does not, however, match the contents of the subject Religion in the Danish uppersecondary schools since the end of the 1980s. 
called "cultural understanding". Thus, the subject of religion from its very beginning in Odense was very employment-oriented, and although with a primary focus on teaching Religion in the upper-secondary schools, the goal was also employment in the broader employment market. Jeppe Sinding Jensen, who was hired in 1982 as Associate Professor in the Study of Religions, was also active in cooperating with the Religion Teachers' Association for the Gymnasium and $\mathrm{HF}^{45}$ in demonstrating the potentials of the subject for dealing with the cultural and religious encounters, for instance for export companies. Tim Jensen, succeeding Sinding Jensen in 1995 when Sinding Jensen moved to a position in Aarhus, came to Odense with ideas not far from those of Sinding Jensen at the time. ${ }^{46}$

The first group of about 20 students began their studies on September 1, 1982. In 1983, Associate Professor Knud Rendtorff was seconded from the Odense Teacher's Training College, an arrangement lasting until his retirement in 2006. Besides the three permanent full-time positions (Thomassen teaching philosophy, Sinding Jensen comparative religion and Rendtorff Christianity and pedagogics), a number of part-time lecturers were borrowed from Classical Studies and History to teach as well. ${ }^{47}$

In 1999, the subject was authorized as a major program. This meant that the department in Odense was now a normal department for the study of religions (the name was Center for Religionsstudier), no longer restricted to the education of Religion teachers as its main (educational) objective. Not without discussion, the hitherto tripartite study program of Philosophy, Christianity and Study of Religions became slowly but surely transformed into a program with the study of religion as the umbrella and defining discipline. In the late 1990s, Poul Götke, a theologian from Aarhus, was hired as Associate Professor in order to teach Christianity, together with Rendtorff, and in 1999 and 2000, historians of religions Mikael Aktor, a PhD from Copenhagen, and Jesper Sørensen, a PhD from Aarhus, were employed as assistant professors.

45 HF: an alternative post-compulsory education sector parallel to the traditional uppersecondary school.

46 During the late 1980s, Tim Jensen together with Jørgen Podemann Sørensen and Mikael Rothstein had established a private consultancy business in order to provide study-of-religionsbased knowledge and know-how to export companies and public institutions.

47 During the 1990s and 2000s, several younger scholars, historians as well as sociologists of religion, many of whom later found permanent employment in Copenhagen or Aarhus, have served in Odense as part-time lecturers. Mention can be made of e.g. Ole Davidsen, Peter B. Andersen, Morten L. Warmind, Kate Østergaard, Dorthe Refslund Christensen, Arun Micheelsen, Kirstine Munk, Nanna Liv Olsen, and Susanne W. Rasmussen. 
With a growing body of employees and students, a full minor and major study program and degree (and with Tim Jensen as Head of the Institute of Philosophy as well as of the Center for Religionsstudier), the Institute of Philosophy became the Institute of Philosophy and the Study of Religions (Religionsstudier) in 2002.

The Ministry of Education and Research had required that a professorial chair be established. The first professorial chair was filled by Olav Hammer. Hammer, who had spent many years working first in the IT sector and then as self-employed (1987-1997) with technical translation, completed a PhD in the history of religions at Lund University in 2000 (Hammer 2001), and immediately afterwards became Assistant Professor at the University of Amsterdam working on Western esotericism in collaboration with Wouter Hanegraaf. In 2004, he was offered a position as Associate Professor in Odense, and in 2005 he became full professor. Hammer's primary research area was and still is 'alternative religions' in Europe, as well as issues of rhetorical legitimation in the history of various religious traditions. His publications thus span the field of Western esotericism, new religious movements, New Age religion, religious polemics, and religion and science.

Each of the members of the study-of-religions staff was expected to continue research in his or her particular field of expertise, but was also required to offer lectures in almost all of the areas of the field, including the history of the research on religion as well as method and theory in the study of religion. This requirement was not due only or primarily to the relatively small number of staff: it was part of a strategic development of the study program towards a teaching profile in tune with the comparative study of religion - and a study program based on ideals not that far from those of Prytz Johansen and Siiger indicated above.

At the end of the 1990s and in the beginning of the 2000s, the curriculum committee emphasized that courses had to include contemporary forms and affairs of the religious traditions taught, as well as contemporary forms and affairs in the world, in Denmark and in the media. The study program thus reflected trends and tendencies to be found elsewhere, but also initiatives taken by Tim Jensen in the early 1990s, for instance in the form of publications on minority religions in Denmark, ${ }^{48}$ and - with Mikael Rothstein - on current ethical developments in religions, not least concerning the global climate crisis.

48 One such publication was Religionsguiden ('Guide to Religion'), one of the first guides to religions and faith communities of immigrants and refugees in Denmark. The fact that Religionsguiden as of the late 1990s also became one of the first websites (hosted by the university) serving also the wider public is telling for the profile and history of the study of religions in Odense. 
At the end of 2004, the Institute of Philosophy and the Study of Religions was dissolved, and as of 2005, the Study of Religions became a study program within a much larger unit, the Institute of Education, Philosophy and the Study of Religions. Apart from the fact that the designations 'department', 'section' or 'center' for the study of religions were now abolished, the change did not matter in terms of research or study program.

In 2006, Annika Hvithamar, a PhD in sociology of religion from Copenhagen and specialist in Russian Christianity, was hired as Assistant Professor, and when theologian Knud Rendtorff retired in 2006 and theologian Poul Götke moved to a position elsewhere, Britt Istoft, a historian of religions specializing in women's religious practises in medieval Christianity, was also hired to teach Christianity. ${ }^{49}$ The staff in Odense thus was the first to break with the tradition of leaving the study and teaching of Christianity to graduates in theology.

During the same period, the philosophical elements of the study program continuously became more integrated within the study-of-religions framework, not only in terms of revisions to the curriculum, but also by offering a doctoral scholarship on the philosophy of religion with a special emphasis on comparative religion. Philosopher Caroline Schaffalitzky de Muckadell won the scholarship, and successfully defended her dissertation on definitions of religion. She is now employed as Associate Professor (formally by another institute than the other lecturers in the study of religions section) primarily responsible for courses and research dealing with religion-related philosophy and with philosophy of science (with special emphasis on theories and concepts of religion, as well as on political philosophy and ethics).

In 2013, both Annika Hvithamar and the sociologist of religion Peter Lüchau moved to positions at the University of Copenhagen. It was subsequently decided to tone down the sociology of religion and instead strengthen the comparative religion profile. A position in comparative religion was therefore advertised and filled in 2013 by Associate Professor Mikael Rothstein, formerly at the University of Copenhagen.

The research profile at Odense is strongly oriented towards contemporary and alternative forms of religions, with Hammer and Rothstein on new and emergent religions, and religion among egalitarian hunter-gatherers and other indigenous peoples; Laura Feldt on religion and popular culture; Mikael Aktor on contemporary forms of Hinduism; and Tim Jensen on contemporary public discourses on religion and on religion education. The

49 Istoft later also became Assistant Professor. 
current curriculum also covers other interests and research areas. Feldt is also a specialist on Mesopotamian and early Christian religion, Aktor on classical Hinduism, Jensen on Greek-Homeric religion, and Assistant Professor Jens-André Herbener on monotheism and religion and nature, and on the Hebrew Bible and Ancient Near Eastern religion. Both Hammer and Rothstein are well-versed in Hellenistic religions. Both the research interests of the Odense faculty, and the curriculum, thus strike a balance between the history of religions past and present.

Mention should be made of the fact that the study program in Odense maintains a special profile with its compulsory courses on a study-of-religions approach to the didactics of religion education in public schools. The education of teachers for the school subject Religion has, as indicated above, played a very important role in developments, be it with regard to teaching, the curriculum, or research, both in Copenhagen and Aarhus, long before the study of religions was established in Odense. Nevertheless, the study of religions in Odense, unlike what was the case in Aarhus and Copenhagen, was from the very first established solely for the purpose of the education of Religion teachers. In addition, the theologian Knud Rendtorff brought with him to the study of religion in Odense from the Teacher's Training College a general pedagogic tradition and subject didactics both of which were almost totally foreign to the universities at the time. Tim Jensen took up this area of research and teaching after Knud Rendtorff. While Rendtorff's research and teaching was for a large part linked to his theological education and to theological, pedagogical, and philosophical approaches to 'almendannelse' (Allgemeinbildung), Jensen came to Odense with a history-of-religions background and 15 years of teaching Religion in the upper-secondary schools. Jensen, consequently, tried to develop, also via international networking and research projects, a study-of-religions-based approach to the didactics of religion education, linking it to general methodological problems within the study of religions. In line with this, the Study of Religions in Odense has earmarked a current doctoral scholarship for the study-of-religions-based religion education didactics. At the moment, the doctoral candidate Karna Kjeldsen, together with Jensen, is participating in an EU (Comenius) project (2013-2015) on religion education and the development of digital teaching materials for the teaching of religion on a study-of-religions-basis.

Mention should also be made of a number of other externally funded research projects involving scholars in Odense. In 2006-2008, Hammer and Jensen directed the international Network for European History of Religions 
(NEUR), ${ }^{50}$ and in 2013 Laura Feldt completed a three-year collaborative research project titled 'On the edge in the wilderness - nature, climate and ambiguous space in ancient religions'. Olav Hammer is currently heading a project that aims at comparing the religious landscape of today with that of Late Antiquity with special regard to agents trying to establish maximalist versions of their religions, and Tim Jensen is currently part of the steering group of an Aarhus-based Research Council funded network called CARD, i.e. Critical Analysis of Religious Diversity: Theory and Method Network.

The total number of students at the study of religions in Odense as of October 2013 was 217

\section{Associations and Journals}

1982 was a significant year for the study of religion in Denmark. Apart from the establishment in Odense of the third study of religions department, other important parallel initiatives were developed independently in Copenhagen and Aarhus. With the establishment around 1980 of the Religionshistorisk Forening ('History of Religions Society') in Copenhagen, and during the late 1970s of the Jydsk Selskab for Religionsvidenskab ('Jutland Society for the Study of Religion') in Aarhus, two scientific journals were launched simultaneously in 1982: CHAOS. Dansk Tidsskrift for Religionshistorie ('Chaos: Danish Journal for the History of Religions') in Copenhagen and Religionsvidenskabeligt Tidsskrift ('Journal for the Study of Religion') in Aarhus. ${ }^{51}$ Today, both journals have successfully published more than 50 issues.

These two societies and journals have contributed significantly to the social and academic environments in Aarhus and Copenhagen respectively. They have, furthermore, contributed to furthering and promoting Danish scholarship of religion by way of inviting scholars from the other Danish universities and from outside of Denmark to come and give lectures, by way of linking up with other academic milieus and co-hosting Scandinavian and international seminars, and establishing and publishing the two journals. They have also served to strengthen the link to former students, not least Religion teachers and the Religion Teachers' Association. The Study of Religions in Odense in 1996 also established a lecture society called

50 A series of books covering the history of religions in Europe from prehistoric times to the present are planned. Apart from several spin-off publications linked to the seminars held under the auspices of their network, only one volume in the planned series has been published so far (Christensen et al. 2013).

51 The latter has had colleagues from both Copenhagen and Odense on the editorial board. 
Religio. Today paying members of Religio are automatically also members of Religionshistorisk Forening. Membership of Religio thus also includes a subscription to $C H A O S$.

In Copenhagen, $C H A O S$ has played a significant role in strengthening links to study of religion colleagues in Scandinavia, especially in Bergen, Norway. In the early 1980s, it became a tradition to have an annual symposium either in Bergen or Copenhagen, and from 1986 CHAOS became Dansk-Norsk Tidsskrift for Religionshistoriske Studier ('Danish-Norwegian Journal for History of Religions Studies'), and the editorial work was shared by Bergen and Copenhagen. This also meant that from then on, CHAOS was issued twice a year, with the one of the two issues consisting of papers read at the joint symposium. Today, CHAOS is Skandinavisk Tidsskrift for Religionshistoriske Studier ('Scandinavian Journal for History of Religions Studies'), and the editorial board is shared by Religionshistorisk Forening in Copenhagen, Norsk Religionshistorisk Forening ('Norwegian History of Religions Society') and Svenska Samfundet för Religionshistorisk Forskning ('Swedish Society for History of Religions Research'). Accordingly, the annual symposia now rotate between several cities, namely Copenhagen, Odense, Bergen, Oslo, Tromsø, and Stockholm. CHAOS is also now itself a publisher, its first publication apart from the journal being Den Sammenklappelige Tid ('Collapsing Time'), a Festschrift for Jørgen Podemann Sørensen, one of the founding fathers of Religionshistorisk Forening and CHAOS.

1982 also saw the foundation of the Danish Association for the History of Religions (DAHR), on the initiative of a group of students and teachers in Aarhus. The presidents of DAHR have been Armin W. Geertz, Aarhus (1982-1994), Jeppe Sinding Jensen, Aarhus (1994-1997), Tim Jensen, Odense (1997-2005), Marianne Qvortrup Fibiger, Aarhus (2005-2007), Annika Hvithamar, Odense (2007-2013), and Jørn Borup, Aarhus (2013-). The DAHR changed its name to the Danish Association for the Study of Religions (Dansk Selskab for Religionsvidenskab - DASR) in 2010 as a reflection of the transformation of the subject from history of religions to the broader study of religion.

As can be seen from the reports on its website covering the period 1982-2009, except for 1994-1997,52 the DAHR expanded all through the 1980s and well up into the 2000s in terms both of membership (from 10 in 1982, 34 in 1986, 43 in 1988, to 56 in 1990) and activities. Some of its biannual conferences were arranged as international conferences and some have

52 See the website $<$ http://www.dasr.dk/english.php>. 
resulted in important publications. In 1984, the DAHR participated in a conference held in Odense on the study of religions at the universities, and in 1995 it coordinated its meeting with a meeting of the Religion teachers in the upper-secondary school.

The DAHR was adopted as a member of the IAHR during the 1985 World Congress of the IAHR in Sydney, Australia. On the initiative of the DAHR leadership and the leadership of the Finnish association, a Scandinavian network was established in Copenhagen in 1988, called Nordisk Samarbejdskomité for Religionshistorie ('Nordic Collaborative Committee for the History of Religions' - NORREL). NORREL functioned well for several years, but despite having the status of a corresponding member of the IAHR, it became inactive. In the late 1990s and early 2000s, Tim Jensen and Nils G. Holm managed to revive NORREL for a while, but then it faded out once again. The DAHR began having problems gathering people for biannual conferences in the late 2000s, and for several years there were no activities. The association has now been revitalized as of November 2013.

An anniversary publication, which has been underway ever since DAHR's 20th anniversary, is currently in the editorial process. The first volume, Religionsforskningen før og nu: Historiske rødder ('The History of the Study of Religion Past and Present: Historical Roots'), by Tove Tybjerg, was published in 2010. A second volume, Religionsforskningen før og nu: Nyere tids forskning ('The History of the Study of Religion Past and Present: Recent Research'), an anthology edited by Geertz and Jensen, will go to press towards the end of 2014.

Leading scholars in Denmark have served on the editorial board of Temenos since its beginning, many of them prominent members of DAHR. Apart from being active in the Nordic network, DAHR was also active internationally, and DAHR leadership was soon actively engaged in the business of the IAHR. It functioned as the distributor of the NAASR journal Method and Theory in the Study of Religions, and in 1990, Armin W. Geertz became Treasurer of the IAHR, and from 1995-2005 he served as its General Secretary. Together with Tim Jensen (then president of the DAHR), Geertz played an active role in the establishment of the European Association for the Study of Religions (EASR) in 2000, and Tim Jensen became the first General Secretary of the EASR (2000-2004). In 2005, Tim Jensen was elected IAHR General Secretary at the IAHR World Congress in Tokyo, thus succeeding Geertz. The DAHR/DASR and its leadership have thus been pivotal in promoting Danish scholarship internationally as well as in the promotion of the academic non-confessional study of religions internationally. 


\section{Conclusion}

Today, the introduction to the study of religions still includes comparative, phenomenological exercises, and the vocabulary resembles to some degree earlier. However, no student comes to the subject without being warned about the typologies and terms we are dealing with. These concepts are not natural givens, first-order things or species out there, but second-order names, analytical terms and scholarly tools inferred by deduction rather than the induction of earlier scholarship. No student can escape the historiography of our key concepts and analytical tools, nor the discussions of the theoretical and methodological problems pertaining to the use of (every kind of) comparison in the study of religions. In this sense, the current situation is new compared to what was the case in the 1970s.

What has not changed, however, is the conviction shared by most Danish scholars, that comparative, cross-cultural studies, be they typological or genetic, are the sine qua non for the study of religions to become a science of religion in general, even though the enterprise must be accompanied and supplemented by more general anthropological and sociological theories and the introduction of themes and concepts like 'authority', 'power' and 'gender'. 53

The three existing departments have also undergone important institutional and organizational changes and transformations in terms of immediate institutional affiliation, e.g. within a Faculty of Theology or a Faculty of Arts (Aarhus), or (Copenhagen) within a larger institute like TORS under the Faculty of the Humanities, and (Odense) within an Institute of Philosophy, then an Institute of Education, Philosophy, and the Study of Religions, and (today) Institute of History. Though these various settings most likely have had an impact on some research schemes, especially collaborative projects, the study of religion(s) in all three universities still has its own specific curriculum. All of these programs have developed in a continuous arc out of previous study-of-religions study programs, and though each program has its own profile, there are significant similarities on all levels of education.

53 Most Danish scholars agree with Sinding Jensen (in his article of 1993 and his 1994 response to Ingvild Gilhus' critique in 1994) when he wrote that the phenomenology of religion is the 'clearing-house of issues related to the production and use of concepts, models and designations in relation to the study of religion'. The Danish approach to the phenomenology of religion is not idealistic, but rather taxonomic and nominalist, in a much more theoretically grounded way than previously. 
Bibliography

\section{Alkjær, Bo}

1989 Jørgen Prytz Johansen, 4.1.1911 - 28.8.1989. - Chaos. Dansk-norsk tidsskrift for religionshistoriske studier 12, 100-11.

Bilde, Per

1981 Fra Kristendomskundskab til Religion. Om den nye eksamensordnings baggrund og perspektiver [From Christian Studies to Religion: On the Background and Perspectives of the New Curriculum Program]. - Nørr, Erik \& Hans Jørgen Lundager Jensen (eds) Religion på universitetet, 112-23. Aarhus: Forlaget Aros

1983 Josefus som historieskriver: en undersøgelse af Josefus' fremstilling af Gaius Caligulas konflikt med jøderne i Palæstina (Bell 2, 184-203 og Ant 18, 261-309) med særligt henblik på forfatterens tendens og historiske pålidelighed [Josephus as Historian: A Study of Josephus' Study on Gaius Caligula's Conflict with the Jews in Palestine (Bell 2, 184-203 and Ant 18, 261-309) with Special Reference to Author's Tendencies and Historical Reliability]. Copenhagen: Gad.

\section{Breengaard, Carsten}

1982 Muren om Israels hus. Regnum og sacerdotium i Danmark 1050-1170 [The Wall Around the House of Israel: Regnum and Sacerdotium in Denmark 1050-1170], København: G.E.C.Gads Forlag.

1993 Religion på universitetet [The Subject of Religion at the University]. - J. K. Krarup et al. (eds), Religionspædagogik i Danmark. [Religion Pedagogics in Denmark]. Frederiksberg: Religionspædagogisk Center.

Christensen, Lisbeth Bredholt \& Olav Hammer \& David A. Warburton (eds)

2013 The Handbook of Religions in Ancient Europe. Durham:Acumen Publishing Ltd.

\section{Duekilde, Vagn}

1997 Hellas i Klassisk Tid. Græsk Religion. [Hellas in Classical Times. Greek Religion]. Copenhagen: Spektrum.

\section{Dumezil, Georges}

1959 Les dieux des Germains ('De nordiske guder,' Danish translation by Vagn Duekilde, Copenhagen: Fremad 1969.) Paris: PUF.

\section{Eliade, Mircea}

1949 Le mythe de l'éternel retour: Archétypes et répétition ('Myten om den evige tilbagekomst: Arketyper og gentagelse,' Danish translation by Vagn Duekilde, Copenhagen: Munksgaard 1966). Paris: Gallimard.

1978 Histoires de croyances et des idées religieuses, 3 vols. ('De religiøse ideers historie,' Danish translation by Vagn Duekilde, 3 vols., Copenhagen: Gyldendal 1983 \& 1995). Paris: Payot. 
Fentz, Mytte

2010 The Kalasha: Mountain People of the Hindu Kush. Humlebæk: Rhodos.

\section{Geertz, Armin W.}

1985 Institut for Religionshistorie 1982-1985 og fremover [Institute for the History of Religions 1982-1985 and in the Future]. - Institut for Religionshistorie, Religionshistorie ved Aarhus Universitet 1960-1985, 22-9. Aarhus: Institut for Religionshistorie.

1989 The Second Warsaw Conference on Methodology and Theory. Temenos. Nordic Journal of Comparative religion 25, 107-8.

1992 The Invention of Prophecy: Continuity and Meaning in Hopi Indian Religion. Knebel: Brunbakke Publications 1992; revised edition Berkeley: University of California Press, 1994.

1995 Religionshistoriens religionsvidenskabelige profil: Tiltrædelsesforelæsning den 1. februar 1995 [The History of Religions as the Study of Religion: Inaugural Lecture 1 February 1995]. Aarhus: Institut for Religionshistorie.

1996 Dansk religionsvidenskabelig forskning i et globalt perspektiv. Nielsen, Kirsten \& Inge M. Bryderup (eds), Dansk teologisk og religionsvidenskabelig forskning, 46-62. Copenhagen: Statens Humanistiske Forskningsråd.

2000a Analytical Theorizing in the Secular Study of Religion. - Tim Jensen \& Mikael Rothstein (eds), Secular Theories on Religion: Current Perspectives, 21-31. Copenhagen: Museum Tusculanum Press.

2000b Global Perspectives on Methodology in the Study of Religion. - Method and Theory in the Study of Religion 12 (1/2), 49-73.

\section{Geertz, Armin W. \& Jeppe Sinding Jensen}

2003 Religionsteoretisk forskning ved Institut for Religionsvidenskab [Theory of Religion Research at the Institute of the Study of Religion]. - André Wang Hansen et al. (eds) Topforskning ved Aarhus Universitet - En jubilæumsantologi [Top Research at Aarhus University - A Jubilee Anthology], 325-64. Aarhus: Aarhus University Press.

\section{Geertz, Armin W. \& Russell T. McCutcheon}

2000 The Role of Method and Theory in the IAHR. - Method and Theory in the Study of Religion 12 (1/2), 3-37.

\section{Gilhus, Ingvild Sælid}

1994 Is a Phenomenology of Religion Possible? A Response to J. Sinding Jensen. - Method and Theory in the Study of Religion 6 (2), 163-71.

\section{Grønbech, Vilhelm}

1909-1912 Vor folkeæt i oldtiden [The Culture of the Teutons]. 4 vols., Copenhagen, English transl. 1931.

1913 Religionsskiftet $i$ Norden [The Change of Religion in the Nordic Countries]. Copenhagen: Gyldendal.

1915 Primitiv religion [Primitive Religion]. Copenhagen: Hans Reitzel. 
1922 Religiøse strømninger $i$ det nittende aarhundrede [Religious Currents in the Nineteenth Century]. Copenhagen.

1932-1934 Mystikere i Europa og Indien [Mystics in Europe and India]. 4 vols., Copenhagen: Gyldendal.

1935 Jesus menneskesønnen [Jesus: Son of Man]. Copenhagen: Gyldendal.

1940a Paulus, Jesu Christi apostel [Paul: Apostle of Jesus Christ]. Copenhagen.

1940b Hellenismen [Hellenism]. 2 vols., Copenhagen: Povl Branner.

1941 Kristus, den opstandne frelser. Den ældste kristne menighed [Christ the Risen Lord: The Oldest Christian Community]. Copenhagen: Gyldendal.

1942 \& 1944-1945 Hellas: Kultur og religion [Hellas: Culture and Religion]. 4 vols., Copenhagen: Povl Branner.

Haarh, Erik

1969 The Yar-Lun Dynasty: A Study with Particular Regard to the Contribution by Myths and Legends to the History of Ancient Tibet and the Origin and Nature of Its Kings. Copenhagen: Gad.

\section{Hammer, Olav}

2001 Claiming Knowledge: Strategies of Epistemology from Theosophy to the New Age. Leiden: E.J. Brill.

\section{Hammer, Olav \& Mikael Rothstein (eds)}

2012 Cambridge Companion to New Religious Movements. Cambridge: Cambridge University Press.

\section{Hvidtfeldt, Arild}

1955 Teotl and *Ixiptlatli: Some Central Conceptions in Ancient Mexican Religion. With a General Introduction on Cult and Myth. Copenhagen: Munksgaard.

1961 Religioner og kulturer. Nogle hovedtræk af den almindelige religionshistorie [Religions and Cultures. Some Features of the General History of Religions]. Copenhagen: Munksgaard.

\section{Institut for Religionshistorie}

1981 Halfdan Siiger og religionshistorien i Århus 1960-1979 [Halfdan Siiger and the History of Religions in Aarhus 1960-1979]. Aarhus: Institut for Religionshistorie.

1985 Religionshistorie ved Aarhus Universitet 1960-1985, [The History of Religions at the University of Aarhus 1960-1985]. Aarhus: Institut for Religionshistorie.

\section{Jensen, Hans Jørgen Lundager}

2004 Den fortærende ild: strukturelle analyser af narrativer og rituelle tekster $i$ Det Gamle Testamente [The Burning Fire: Structural Analyses of Narratives and Ritual Texts in the Old Testament]. Aarhus: Aarhus Universitetsforlag. 


\section{Jensen, Jeppe Sinding}

1993 Is a Phenomenology of Religion Possible? On the Ideas of a Human and Social Science of Religion. - Method and Theory in the Study of Religion 5 (2), 109-33

1994 The Name of the Game is 'Nominalism'. A Response to I.S. Gilhus. Method and Theory in the Study of Religion 6 (3), 277-284.

2003 The Study of Religion in a New Key: Theoretical and Philosophical Soundings in the Comparative and General Study of Religion (Studies in Religion 3). Aarhus: Aarhus University Press.

\section{Jensen, Povl Johannes}

1979 Københavns Universitet 1479-1979, [The University of Copenhagen 1479-1979], vol. 11. Copenhagen: University of Copenhagen.

\section{Jensen, Povl Johannes \& Leif Grane}

1992 Københavns Universitet 1479-1979, [The University of Copenhagen 1479-1979], vol. 8. Copenhagen: University of Copenhagen.

\section{Jensen, Tim}

2002 From History of Religions to the Study of Religions: Trends and Tendencies in Denmark. - G. Sfameni Gasparro (ed), Themes and Problems of the History of Religions in Contemporary Europe, 183-208. Cocenza: Edizioni Lionello Giordanao.

2007 The Study of Religions and Religion in Denmark. - Nederlands Theologisch Tijdschrift 61 (4), 229-342.

\section{Jensen, Tim \& K. Kjeldsen}

2013 RE in Denmark - Political and Professional Discourses and Debates, Past and Present. - Temenos. Nordic Journal of Comparative Religion 49 (2), 185-223.

\section{Johansen, Jørgen Prytz}

1954 The Maori and his Religion in its Non-Ritualistic Aspects. Copenhagen: University of Copenhagen.

1958 Studies in Maori Rites and Myths. Copenhagen: Munksgaard.

1979 Religionshistorie [The History of Religions]. - Jensen, Povl Johannes, Københavns Universitet 1479-1979, 1-48. Vol. 11. Copenhagen: University of Copenhagen.,

\section{Lehmann, Edvard}

1899-1902 Zarathustra, En Bog om Persernes gamle Tro. [Zarathustra: A Book on the Ancient Beliefs of the Persians], 2 volumes. Copenhagen: Det Schubotheske Forlag.

\section{Monberg, Torben}

1978 Mungiki: kulturen og dens religion på øen Bellona i Stillehavet [Mungiki: The Culture and Its Religion on the Island of Bellona in the Pacific]. Copenhagen: Gyldendal. 
1991 Bellona Island: Beliefs and Rituals. Honolulu: University of Hawai'i Press.

Nielsen, Kirsten \& Inge M. Bryderup (eds)

1996 Dansk teologisk og religionsvidenskabelig forskning [Danish Theological and Study of Religion Research]. Copenhagen: Statens Humanistiske Forskningsråd.

Nørr, Erik

1981 Kristendomskundskabs-studiets oprettelse og første udvikling indtil 1920 [The Establishment and Early Developments of Christian Studies Curriculum until 1920]. - Erik Nørr \& Hans Jørgen Lundager Jensen (eds), Religion på universitetet, 26-47. Aarhus: Forlaget Aros.

Nørr, Erik \& Hans Jørgen Lundager Jensen (eds)

1981 Religion på universitetet, [Religious Studies at the University], Aarhus: Forlaget Aros.

\section{Pallis, Svend}

1918 Mandriske Studier [Mandaen Studies]. Copenhagen: University of Copenhagen.

1926 The Babylonian Akîtu Festival (Historisk-filologiske Meddelelser 12, 1). Copenhagen: Det Kgl. Danske Videnskabernes Selskab.

1948 Greek Religious Texts, Selected and Edited with Critical Notes. Copenhagen: Povl Branner.

\section{Petersen, Anders Klostergaard}

1994 Paulus' forståelse af den kristne dåb som hermeneutisk nogle til hans teologi. En teologisk afhandling over dåbens placering og funktion i den paulinske teologi. [Paul's Understanding of the Christian Baptism as a Hermeneutical Key to His Theology: A Theological Dissertation on the Place and Function of Baptism in Paul's Theology]. Aarhus: Det Teologiske Fakultet.

\section{Pye, Michael (ed)}

1989 Marburg Revisted: Institutions and Strategies in the Study of Religion. Marburg: Diagonal Verlag.

\section{Raudvere, Catharina}

1993 Föreställningar om maran i nordisk folktro [Conceptions of Goblins in Nordic Folk Beliefs] (Lund Studies in History of Religions 1). Lund: Religionshistoriska avdelingen.

\section{Reeh, Niels}

2006 Religion and the State of Denmark. State Religious Politics in the Elementary School System from 1721 to 1975: An Alternative Approach to Secularization. Copenhagen: University of Copenhagen. 


\section{Rothstein, Mikael}

1993 The Relation between Science and Religion in Transcendental Meditation (TM) and the International Society for Krishna Consciousness (ISKCON). Aarhus: Aarhus University Press.

\section{Sand, Erik Reenberg \& Jørgen Podemann Sørensen (eds)}

2001 Edvard Lehmann og religionshistorien. Et symposium ved fagets 100-års jubilæum i Danmark [Edvard Lehmann and the History of Religions. A Symposium on the 100th Anniversary of the Subject in Denmark]. Copenhagen: Institut for Religionshistorie.

\section{Schjødt, Jens Peter}

2003 Initiation, liminalitet og tilegnelse af numinøs viden : En undersøgelse af struktur og symbolik i førkristen nordisk religion [Initiation, Liminality and the Gain of Numinous Knowledge: A Study of Structure and Symbolism in Pre-Christian Norse Religion]. Aarhus: Det Teologiske Fakultet.

\section{Siiger, Halfdan}

1956 From the third Danish expedition to Central Asia: Ethnological field-research in Chitral, Sikkim, and Aseam: Preliminary report. (Historisk-filologiske Meddelelser udg. af Det kongelige Danske Videnskabernes Selskab; Volume 36, No. 2). Copenhagen: Ejnar Munksgaard.

1967 The Lepchas: Culture and Religion of a Himalayan People, 2 volumes. Copenhagen: The National Museum of Denmark.

\section{Smidt Hansen, Bent}

1985 Træk af instituttets historie 1960-1982 [Incidents in the History of the Institute 1960-1982]. - Institut for Religionshistorie 1985, 7-21.

\section{Stenbæk, Jørgen}

1980 Universitetsuddannelsen i kristendomskundskab/religion [The University Educational Program in Christian Studies/Religion]. Kirkehistoriske Samlinger 1980, 225-47.

1981 Hovedfag eller bifag. Universitetsuddannelsen i Kristendomskundskab fra 1920-34 [Major or Minor. University Education in Christian Studies from 1920-34]. - Erik Nørr \& Hans Jørgen Lundager Jensen (eds), Religion på universitetet, 48-72. Aarhus: Forlaget Aros.

\section{Sørensen Podeman, Jørgen (ed)}

1989 Rethinking Religion. Studies in the Hellenistic Process. Copenhagen: Museum Tusculanum Press.

2012 Ritual Texts: Language and Action in Ritual.- John P. Hoffmann (ed.), Understanding Religious Ritual: Theoretical approaches and innovations, 73-92. London: Routledge.

\section{Thomassen, Niels}

1982 Religion ved Odense Universitet [Religion at Odense University]. Nyt fra Odense Universitet 8. 


\section{Tybjerg, Tove}

1996 Religionsvidenskabelig forskning i perioden 1970-95 - status og perspektiver [Research in the Study of Religion during the Period 1970-95: Status and Perspectives]. - Kristen Nielsen \& Inge M. Bryderup (eds), Dansk teologisk og religionsvidenskabelig forskning, 23-37. Copenhagen: Statens Humanistiske Forskningsråd.

2010 Religionsforskningen før og nu: Historiske rødder [The Study of the History of Religions Past and Present: Historical Roots]. Copenhagen: Gyldendal. (Vol. 1 of Religionsforskningen for og nu, edited by Armin W. Geertz and Tim Jensen.)

Tyloch, Witold (ed.)

1990 Studies on Religions in the Context of Social Sciences: Methodological and Theoretical Relations. Warsaw: Polish Society for the Science of Religions

\section{Vanggaard, Jens Henrik}

1988 The Flamen. A Study in the History and Sociology of Roman Religion. Copenhagen: Museum Tusculanum Press

\section{Warburg, Margit}

1978 Religion igymnasiet, HF og seminariet. Forholdet mellem retsgrundlaget og undervisningsmaterialernes indhold, holdninger og pædagogiske principper [The Subject of Religion in the Upper-Secondary Schools, HF and the Teacher's Colleges. The Relations between Rules and Regulations and the Contents, Attitudes and Pedagogical Principles in the Educational Materials], 2 vols. Copenhagen: Institut for Religionssociologi.

2006 Citizens of the World: a History and Sociology of the Baha'is from a Globalisation Perspective. Leiden: Martinus Nijhoff Publishers. 
